\title{
ULTRASOUND ASSISTED BIO-DYEING OF SOME TEXTILE MATERIALS WITH BLACK CARROT (DAUCUS CAROTA L.) EXTRACT
}

\author{
HÜSEYİN BENLİ \\ Mustafa Çıkrıkçığlu Vocational School, Chemistry and Chemical Processing Technologies Department, \\ Kayseri University, Yenidoğan Mahallesi Turhan Baytop Sokak 38280, \\ Talas, Kayseri, Turkey \\ ๑ Corresponding author: hbenli@kayseri.edu.tr
}

Received August 19, 2020

\begin{abstract}
This study has been conducted to find out whether black carrot extract can be used as a dyestuff to dye textile materials. For this purpose, the two most widely used textiles (namely, cotton and wool) have been selected. The extractions from the black carrot were performed directly in the dyebath. An ultrasonic bath at $80{ }^{\circ} \mathrm{C}$ for 60 minutes was used to increase extraction efficiency. All the dyeing processes were carried out at $100{ }^{\circ} \mathrm{C}$ for 60 minutes, both with and without some metal salts, using two different dye concentrations in 1:1 and 1:10 ratios (material weight:dye extraction volume). Six different metal salts, i.e. $\mathrm{K}_{2} \mathrm{Cr}_{2} \mathrm{O}_{7}, \mathrm{CuSO}_{4} 5 \mathrm{H}_{2} \mathrm{O}, \mathrm{FeSO}_{4} 7 \mathrm{H}_{2} \mathrm{O}, \mathrm{SnCl}_{2} 2 \mathrm{H}_{2} \mathrm{O}, \mathrm{ZnSO}_{4} 7 \mathrm{H}_{2} \mathrm{O}, \mathrm{KAl}\left(\mathrm{SO}_{4}\right)_{2}$. $12 \mathrm{H}_{2} \mathrm{O}$, were used in the dyeing processes, according to pre- and simultaneous mordanting methods. After the dyeing processes, the dyed samples' CIE $L * a * b *$ and color efficiency $K / S$ values were determined by spectrophotometry. The SEM and FTIR data of the fabrics were collected and evaluated at the end of the trials as well. At the same time, perspiration, rubbing, washing and light fastness values of the dyed materials were also assessed. Acceptable fastness test results were obtained for the dyed samples. The findings of the study indicated that the dyeability performance of wool and cotton fabrics with black carrot (Daucus carota L.) extract could be greatly influenced by the mordant used and its application method.
\end{abstract}

Keywords: black carrot, Daucus carota L., anthocyanins, textile, dyes, ultrasound

\section{INTRODUCTION}

Today, the most widely used natural textile materials in the world are cotton and wool. A wide variety of chemical-based dyestuffs are used for coloring such materials. In dyehouses, large amounts of chemical-based synthetic dyes, with harmful and toxic wastes, are used. Although synthetic dyes perform very well, it is also possible to color textile materials with environmentally friendly, antiallergic, non-toxic dyes, ${ }^{1}$ which have been investigated as an alternative in many studies in recent years. One of the efforts of such works, perhaps the most important, is to revive and spread natural dyestuffs that have lost their importance with the popularity of synthetic dyestuffs. Currently, the known natural dyes originate from herbal, animal and mineral sources, ${ }^{2}$ the most preferred of them being those of herbal origin. ${ }^{3}$ Generally, in the coloring process, many different parts of plants, such as roots, stems, branches, leaves, bark, flowers, seeds and fruits are used. ${ }^{4}$ Natural dyes and dyeing processes in the textile industries are literally of great interest due to increasing awareness of water pollution, sustainability of raw materials and processed products, biodegradability and environmental protection. ${ }^{5}$

In the present study, the coloring properties of black carrot extract were investigated. Black carrot (Daucus carota L.), which has been known for about 3000 years, ${ }^{6}$ has very high anthocyanin contents, ${ }^{7}$ which are the type of pigments responsible for the purple, blue and red colors of fruits, flowers and vegetables. ${ }^{8}$ It is mainly cultivated in Asia, Europe and Africa. ${ }^{9}$ Besides, it has been reported that anthocyanin pigments serve as attractants for pollination and seed spread, protect against the detrimental effects of ultraviolet irradiation, and ensure antimicrobial and antiviral activities. ${ }^{10}$

In addition to the color properties, literature studies have shown that anthocyanins have a positive effect on human health. For example, 
Wrolstad $^{10}$ highlighted the potential role of anthocyanin pigments in reducing the risk of coronary heart disease, stroke and cancer. Pant and Manandhar ${ }^{11}$ mentioned the conventional use of black carrot in the treatment of ancylostomiasis, dropsy, bladder afflictions and chronic kidney diseases. Furthermore, multifarious pharmacological actions, such as antibacterial, $^{12} \quad$ antifungal, $\quad$ cytotoxic, ${ }^{13}$ anthelmintic, hepatoprotective, ${ }^{14}$ antimicrobial and against breast cancer proliferation, ${ }^{15}$ have been found for black carrot. Also, Netzel et al. ${ }^{16}$ reported evidence of the cancer cell antiproliferation activity of an anthocyanin-rich black carrot extract. It has been also demonstrated that black carrot anthocyanins provide a great bright strawberry-red shade at acidic $\mathrm{pH}$ and can be a good alternative for coloring confectionery, soft drinks, fruit juices, jellies, conserves, nectars. ${ }^{17-18}$ In addition, several studies concluded that it is possible to obtain powdered anthocyanins from black carrots, especially for use in coloring of foodstuffs. ${ }^{18-19}$ Other research works have investigated the possibility to produce dye sensitized solar cells with black carrot (Daucus carota L.) juice. ${ }^{20-26}$

In this study, the ultrasound technology was used to obtain more effective black carrot extraction. The ultrasound technology has found significant use in many different areas of textile dyeing and finishing. The phenomenon of bubble formation and collapse (known as acoustic cavitation) created by ultrasonic waves is usually considered liable for most of ultrasound's physical and chemical effects monitored in solid/liquid or liquid/liquid systems. ${ }^{27}$ Cavitation is a physical event, creating very small vacuum bubbles (not visible to the naked eye) in a liquid, filled with vapor, gas or a mixture to a certain degree thereof, which under certain circumstances implode. ${ }^{28}$ These cavities are formed into a liquid when the static pressure of the liquid, for one reason or another, is cut below the vapor pressure of the liquid at a certain temperature. When cavities are moved to higher-pressure regions, they implode strongly, causing powerful shock waves. ${ }^{29}$ Various studies on the uses of ultrasonic energy in the textile industry, especially on wet processes, such as pretreatment, ${ }^{27,30}$ dyeing, ${ }^{31-35}$ and finishing, ${ }^{36,37}$ have been encountered in recent years. Perincek et $a l^{29}$ determined the requirements for an industrial scale ultrasonic bath needed for the textile industry. We conducted two separate studies involving the use of ultrasounds in 2015: in the first, the pretreatment and dyeing of fabric was combined with ultrasonic energy and ozone gas, ${ }^{38}$ in the other, the pretreatment and dyeing operations were carried out in a single bath containing different enzymes using ultrasonic energy. ${ }^{39}$

Natural dyeing is not a novel subject in the research literature. Thus, for example, Ren et al. ${ }^{59}$ reported on a novel dyeing mechanism for cellulose fibers with tea pigments, based on insitu polymerization. Lohtander et al. carried out a semi-quantitative study of willow bark dye adsorption on two different cellulose materials (microcrystalline cellulose and regenerated Ioncell-F), using bio-mordants. ${ }^{60}$ To promote biobased materials in textile dyeing and finishing, Ul-Islam and Butola $^{61}$ used chitosan in combination with Citrus sinensis peel extract as an approach to enhance the natural dyeing performance of cotton fabric under optimum conditions. The present study aimed to explore the potential of black carrot extract for being used as a natural, environmentally friendly dyestuff for textile materials.

\section{EXPERIMENTAL \\ Materials}

In this study, $100 \%$ cotton and wool fabrics of 300 and $250 \mathrm{~g} / \mathrm{m}^{2}$, respectively, were used. Black carrot was purchased from a local market in Turkey (Fig. 1 (a)) and was used for the coloration of wool and cotton fabrics. $\mathrm{NaOH}, \mathrm{H}_{2} \mathrm{O}_{2}(50 \%), \mathrm{Na}_{2} \mathrm{CO}_{3}$ and other metal salts used were of analytical grade.

Black carrots have much higher amounts of flavonoid compounds, compared to orange and red cultivars. Quercetin (Fig. 1(b)), luteolin (Fig. 1(c)), myricetin (Fig. 1(d)) and kaempferol (Fig. 1(e)) have been identified as the primary flavonoids existing in carrots. $^{40-41}$

\section{Methods}

A comprehensive experimental study was carried out to detect the ability of black carrot extract to dye textile materials and characterize the dyed samples. The experimental plan applied in this study is presented in detail in Figure 2.

\section{Pretreatment of cotton and wool samples}

Pretreatment of cotton fabric is required to remove natural (coloring matter, waxes, fat, pectins etc.) and human-induced impurities. ${ }^{42}$ Since the grey cotton woven fabric used in the trials was starch-based, it was subjected to pretreatment processes, such as desizing, scouring and bleaching, before proceeding with dyeing. It is known that the main objectives in cotton pretreatment are obtaining satisfactory absorbency, 
complete removal of the seed-coat part and the achievement of sufficient whiteness. ${ }^{43}$ The main purpose of these processes is to obtain a smooth dyeing surface. $^{44}$ The traditional pretreatment recipe applied to cotton and wool fabric is given in Table 1.

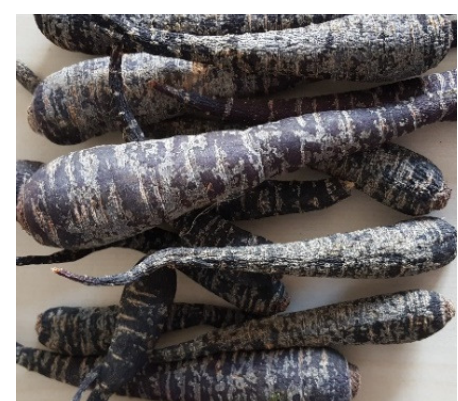

(a) black carrot<smiles>O=c1c(O)c(-c2ccc(O)c(O)c2)oc2cc(O)cc(O)c12</smiles>

(b) Quercetin<smiles>O=c1c(O)c(-c2cc(O)c(O)c(O)c2)oc2cc(O)cc(O)c12</smiles>

(d) Myricetin

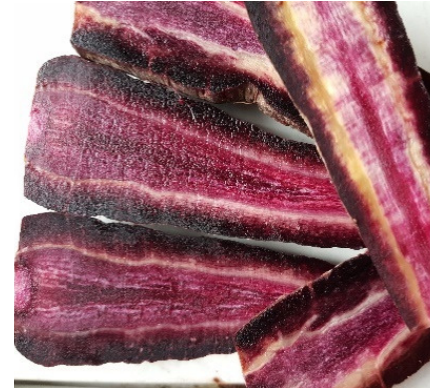<smiles>O=c1cc(-c2ccc(O)c(O)c2)oc2cc(O)cc(O)c12</smiles>

(c) Luteolin<smiles>O=c1c(O)c(-c2ccc(O)cc2)oc2cc(O)cc(O)c12</smiles>

(e) Kaempferol

Figure 1: Black carrot and its chemical compounds

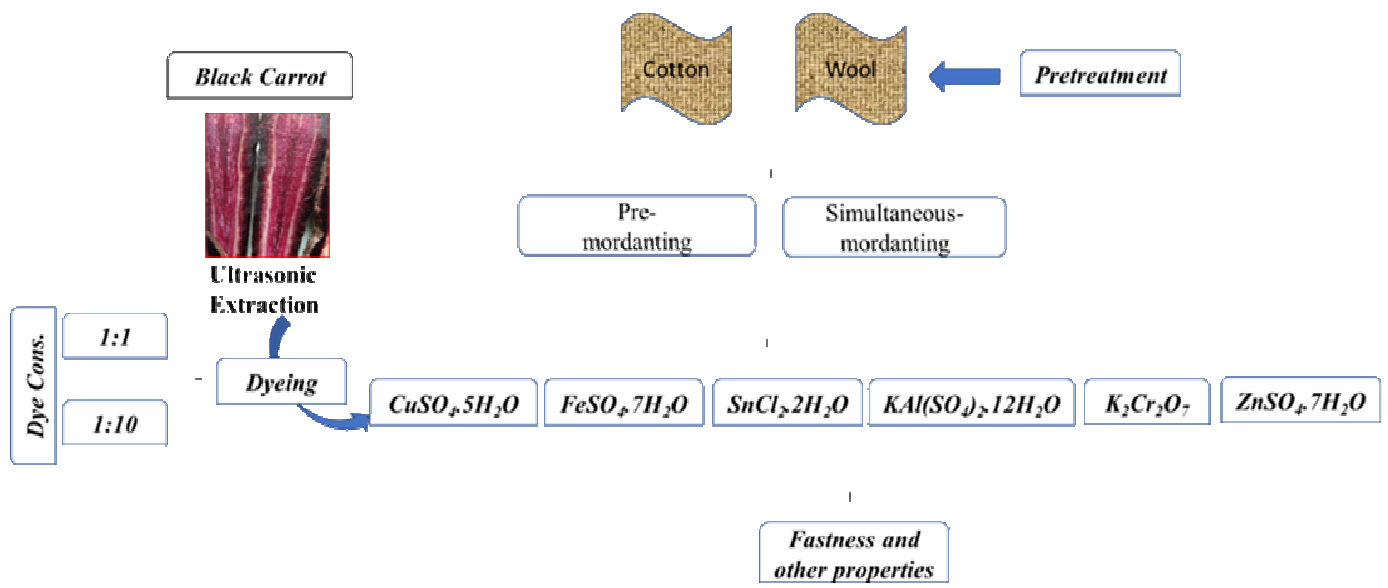

Figure 2: Schematic diagram applied in all experiments

At the end of the conventional pretreatment processes, changes occurred on the cotton fabric and some tests were conducted on the fabric to characterize them. The desizing degrees of the cotton fabrics were determined by dripping iodine/potassium iodide solution. The output of the reaction occurring between starch and the iodine solution was assessed by the Tegewa scale. Afterwards, the hydrophilicity of the samples was analyzed by vertical wicking of fabrics in warp direction and determining the rising height. ${ }^{45}$ 


\section{HÜSEYIN BENLI}

Lastly, the whiteness degrees of the fabrics were obtained by the Stensby formula, using data collected by a Konica Minolta 3600d Model Spectrophotometer.

\section{Ultrasound assisted extraction of black carrot}

In this study, ultrasound technology was used for an effective extraction of black carrot in water. Although some researchers used solvents, such as ethanol, methanol and chloroform, in this study, solely water was used for an environmentally friendly process. An ultrasonic bath (Wiseclean) with a volume of $2 \mathrm{~L}$, at $28 \mathrm{KHz}$ frequency, was used for ultrasonic treatment. Before all the dyeing processes, the extract of black carrot was first obtained at $80{ }^{\circ} \mathrm{C}$ for 60 minutes. Then, these extracts were used as a dye bath for dyeing textile materials.

Table 1

Conventional pretreatment of raw cotton and wool fabrics

\begin{tabular}{|c|c|c|c|c|c|c|c|}
\hline Material & Pretreatment & Chemical & Quantity & $\begin{array}{l}\text { Liquor } \\
\text { ratio }\end{array}$ & $\mathrm{pH}$ & $\begin{array}{c}\text { Temperature } \\
\left({ }^{\circ} \mathrm{C}\right)\end{array}$ & $\begin{array}{l}\text { Time } \\
(\min )\end{array}$ \\
\hline \multirow{3}{*}{$\begin{array}{l}\text { Cotton } \\
\text { fabric }\end{array}$} & Desizing & $\begin{array}{c}\alpha \text {-amylase } \\
\text { Nonionic } \\
\text { wetting agent }\end{array}$ & $\begin{array}{c}4 \mathrm{~g} / \mathrm{L} \\
1.5 \mathrm{~g} / \mathrm{L}\end{array}$ & $1: 20$ & 6 & 60 & 60 \\
\hline & Scouring & $\begin{array}{c}\mathrm{NaOH} \\
\mathrm{Na}_{2} \mathrm{CO}_{3} \\
\text { Nonionic } \\
\text { wetting agent }\end{array}$ & $\begin{array}{c}2 \% \\
2 \% \\
1 \mathrm{~g} / \mathrm{L}\end{array}$ & $1: 20$ & $10.5-11$ & 95 & 60 \\
\hline & Bleaching & $\begin{array}{c}\mathrm{H}_{2} \mathrm{O}_{2}(50 \%) \\
\mathrm{NaOH} \\
\text { Stabilizing agent }\end{array}$ & $\begin{array}{c}3 \mathrm{~mL} / \mathrm{L} \\
1 \mathrm{~g} / \mathrm{L} \\
0.5 \mathrm{~mL} / \mathrm{L}\end{array}$ & $1: 20$ & $9-10.5$ & 95 & 60 \\
\hline $\begin{array}{l}\text { Wool } \\
\text { fabric }\end{array}$ & Washing & $\begin{array}{c}\text { Nonionic } \\
\text { wetting agent }\end{array}$ & $1.5 \mathrm{~g} / \mathrm{L}$ & $1: 20$ & $6-7$ & 40 & 10 \\
\hline
\end{tabular}

\section{Mordanting}

Dyeing of textile materials with herbal based dyestuff often causes problems, such as limited shade range and inadequate color fastness of the dyed textiles. Metal salts called mordants are used to reduce these problems. In addition to forming an affinity between the dye molecule and the material, the use of mordanting agents also changes the hue of dye solutions. ${ }^{46}$ It has been demonstrated that mordanting methods usually improve the dye efficiency and help achieve a broad spectrum of colors on a wide range of natural and synthetic fibers, with enlarged shade ranges and better fastness properties. ${ }^{47}$ The most commonly used mordants in herbal based dyeing are alum, stannous chloride, potassium dichromate, copper sulphate and ferrous sulphate. ${ }^{1,46,47}$ In this study, preand simultaneous mordanting methods were used, applying $\quad \mathrm{K}_{2} \mathrm{Cr}_{2} \mathrm{O}_{7} \quad(3 \%), \quad \mathrm{CuSO}_{4} 5 \mathrm{H}_{2} \mathrm{O} \quad(3 \%)$, $\mathrm{FeSO}_{4} 7 \mathrm{H}_{2} \mathrm{O}(3 \%), \mathrm{SnCl}_{2} 2 \mathrm{H}_{2} \mathrm{O}(3 \%), \mathrm{ZnSO}_{4} 7 \mathrm{H}_{2} \mathrm{O}(3 \%)$ and $\mathrm{KAl}\left(\mathrm{SO}_{4}\right)_{2} \cdot 12 \mathrm{H}_{2} \mathrm{O}(20 \%)$ metal salts. In the premordanting process, after the textile material was treated at $100{ }^{\circ} \mathrm{C}$ for 60 minutes with the metal salt, dyeing was started. In the simultaneous mordanting method, the metal salt, the herbal based dyestuff and the textile material to be dyed were put together in the same dye-bath and processed at $100{ }^{\circ} \mathrm{C}$ for 60 minutes.

\section{Dyeing}

The black carrot extract was obtained in the ultrasound bath and used as a direct dye solution. The dyeing processes were carried out with two different dye concentrations (1:1 and 1:10), that is, the herbal based dyestuff was set to be the same (1:1) weight or ten $(1: 10)$ times higher than the textile material weight. The extracted black carrot juice was used directly as a dye bath. Ultrasonic extraction was carried out with water 20 times $(\mathrm{L}: \mathrm{R}=1 / 20)$ the weight of the material to be dyed. All dyeing processes were performed in a closed environment (HT) at $100{ }^{\circ} \mathrm{C}$ for 60 minutes. After the dyeing processes, the dyed samples were subjected to the warm wash - hot soap wash (1 g/L non-ionic surfactants for 10 minutes) - hot rinse sequence as post-treatment and then were dried at room temperature.

\section{$U V$-vis spectroscopy}

The UV-vis absorbance values of the black carrot extract used in the laboratory dyeing trials were measured with a UV-3100PC spectrophotometer (VWR). The absorbance measurements were made in the $350-750 \mathrm{~nm}$ range, with a $1 \mathrm{~nm}$ step.

\section{Color value and efficiency}

The dyed wool and cotton fabrics were evaluated in terms of color efficiencies $(K / S)$ and $C I E L^{*} a * b *$ color space values using a Konica Minolta 3600d Spectrophotometer $\left(\mathrm{D} 65 / 10^{\circ}\right)$. The $K / S$ value was calculated by the Kubelka-Munk equation: ${ }^{48}$

$K / S=(1-\mathrm{R})^{2} / 2 \mathrm{R}$ 
where $R$ is reflectance, $L^{*}$ describes lightness $(100=$ white, $0=$ black), $a^{*}$ measures redness or greenness, $b^{*}$ measures yellowness or blueness in the CIE system.

\section{Color fastness properties}

The fastness properties of the dyed wool and cotton samples were investigated in terms of resistance to rubbing, perspiration, light and washing. The washing fastness was determined following ISO $105-\mathrm{C} 10^{49}$ standard under test condition of Test A (1), perspiration fastness - ISO $105-\mathrm{E} 04^{50}$ standard, light fastness - ISO $105-\mathrm{B} 02^{51}$ standard and rubbing fastness - ISO $105-\mathrm{X} 12^{52}$ standard.

\section{SEM analysis}

The surfaces of raw wool and cotton fabrics, as well as the changes occurring in the dyed specimens, were investigated using a high resolution field emission SEM (Zeiss evo LS10).

\section{FTIR analysis}

IR characterizations of the raw wool and cotton fabrics, as well as the dyed samples, were performed using a Perkin Elmer 400 FT-IR/FT-FIR Spectrometer (with the resolution of $2 \mathrm{~cm}^{-1}$ ) Spotlight 400 .

\section{RESULTS AND DISCUSSION}

Conventional pretreatments are an essential step in dyeing cotton fabric, particularly, for achieving a smooth dyeing surface, enough hydrophilicity and whiteness of the fabrics. For this, desizing, scouring and bleaching processes were conducted on the raw materials. As can be seen from Table 2, after the desizing process, it was established that the starch sizing agent was widely degraded and removed from the fabric. Among other things, the whiteness and hydrophilicity values were low, but both of them increased with the scouring process.

Finally, at the end of the bleaching process, the whiteness, hydrophilicity and desizing values obtained were: 81.2 (Stensby), $26(\mathrm{~mm} / 90 \mathrm{~s})$ and 8 (Tegewa scale), respectively. These results make the cotton fabric samples suitable for dyeing.

In the present study, the black carrot extract was used as a natural dyestuff for dyeing wool and cotton fabrics. The chemical structures of quercetin, luteolin, myricetin and kaempferol compounds existing in black carrot are shown in Figure 1. The schematic representation of the possible interaction mechanism between the natural dye molecules (for instance, quercetin) and the woolen/cotton fabric structure, through the mordanting process, is shown in Figure 3. A complex is formed between the metal salt and the bio-dye molecules, which is bound to the textile material, forming a complex structure.

\section{UV-vis spectroscopy of black carrot extract}

In this study, an extract of black carrot was used to dye textile materials. The color components of the black carrot (Fig. 1) were solubilized into the aqueous medium, assisted by the ultrasonic energy, and then the textile materials were dyed with this aqueous solution obtained. During the extraction process, no solvents, such as methanol, ethanol or acetone, were used. The wavelengths of the absorbance of the solution obtained from the black carrot extraction in the aqueous medium are presented in Figure 4.

It can be noted that the maximum absorbance value of the black carrot aqueous solution was $590 \mathrm{~nm}$. Vankar reported that the visible spectrum of the black carrot extract shows peaks in the region $525-660 \mathrm{~nm}^{53}$ The following UV-visible absorbance and lambda values of the black carrot extract were recorded: $590 \mathrm{~nm}(0.7777), 584 \mathrm{~nm}$ (0.7710), $528 \mathrm{~nm}(0.1679), 512 \mathrm{~nm}(0.3199), 488$ $\mathrm{nm}(0.2604)$ and $460 \mathrm{~nm}(0.2800)$.

\section{Colors and CIE $L * a * b *$ values obtained using black carrot extract Dyeing without mordant agents}

In the first part of this study, dyeing was performed using the black carrot extract without any metal salts added. The colors obtained are presented in Table 3. It has been noticed that the color becomes darker as the dye concentration increases. In addition, it has been determined that woolen fabrics have darker shades than cotton fabrics. While the colors obtained for cotton fabrics are usually buff shades, those achieved on wool fabric are pale-dark purple, as shown in Table 3. Though the same bio-dyestuff is used, the most important reason of this color difference between cotton and woolen fabrics is thought to be the presence of many amino (-NH) and carboxyl (-COOH) groups in the chemical structure of wool.

The $K / S$ values obtained for the dyed wool fabric samples (three different dye concentrations), without using any mordant agent, were $0.66,0.99,2.69$, respectively, whereas they were $0.11,0.35$ and 0.88 for the cotton fabric samples. 


\section{HÜSEYIN BENLI}

Table 2

Results obtained after conventional pretreatment processes of cotton fabrics

\begin{tabular}{cccc}
\hline $\begin{array}{c}\text { Cotton } \\
\text { Appl. types }\end{array}$ & $\begin{array}{c}\text { Desizing degree } \\
\text { (Tegewa scale) }\end{array}$ & $\begin{array}{c}\text { Hydrophilicity } \\
(\mathrm{mm} / 90 \mathrm{~s})\end{array}$ & $\begin{array}{c}\text { Whiteness degree } \\
\text { (Stensby) }\end{array}$ \\
\hline P1 & 3 & 7 & 51.3 \\
P2 & 5 & 13 & 60.5 \\
P3 & 8 & 26 & 81.2 \\
\hline (P1: Desized cotton fabric; P2: Scoured cotton fabric; P3: Bleached cotton fabric)
\end{tabular}
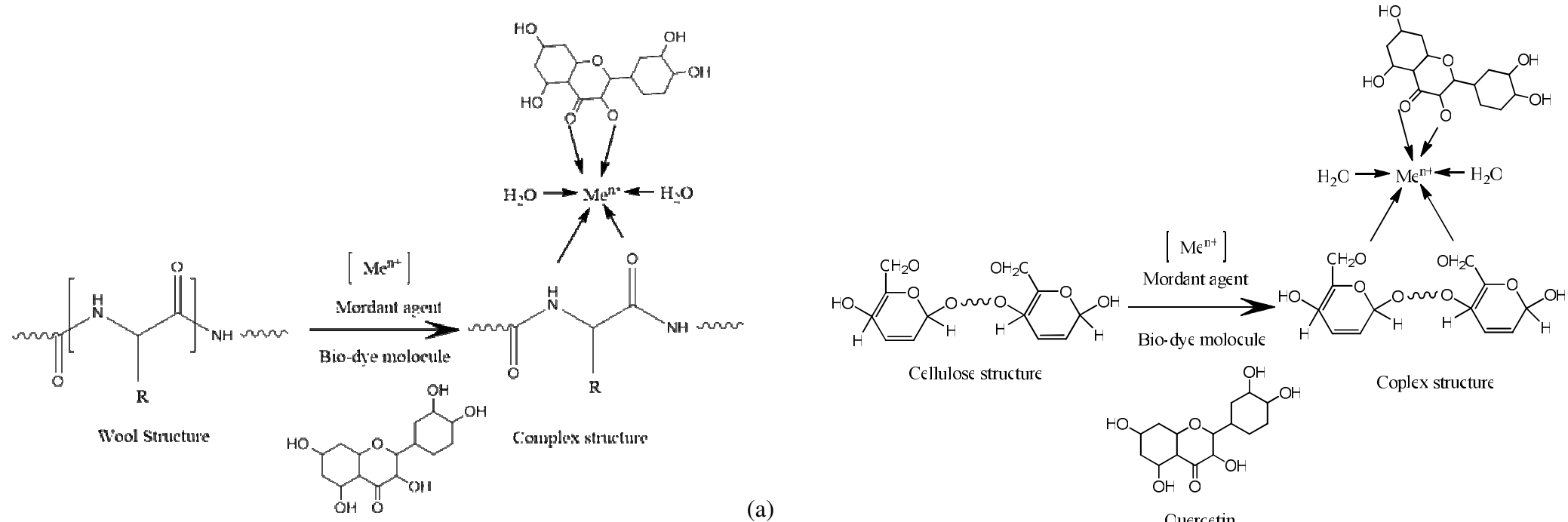

Cellulose structure

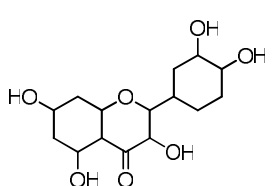

Coplex structure (a)

Figure 3: Complex chemical structure between wool/quercetin (a) and cotton/quercetin (b) 


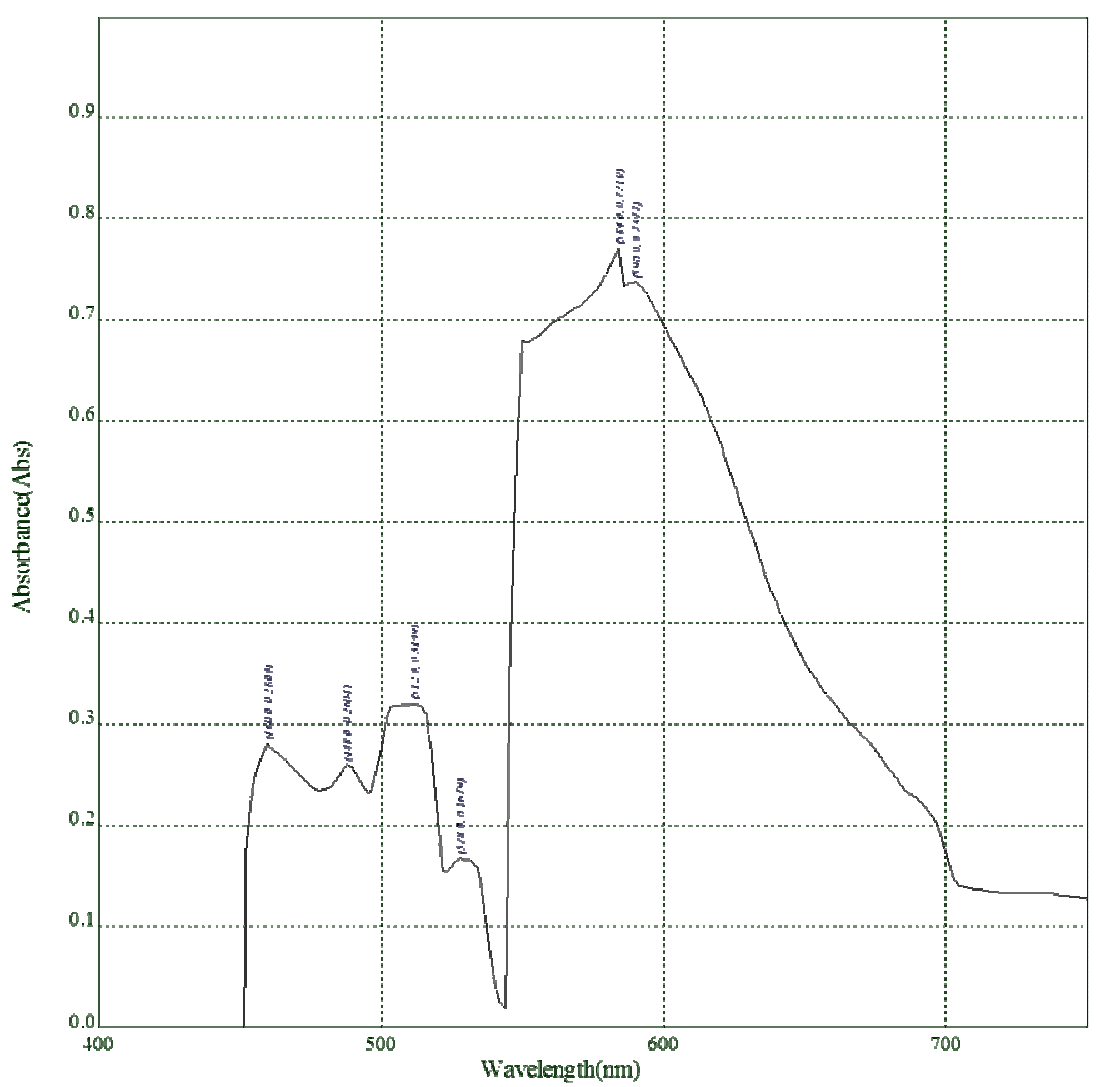

Figure 4: UV visible spectrum of black carrot aqueous extract

At the same time, for the dyed wool fabrics, the $a^{*}$ and $b^{*}$ values obtained were the following: -2.07, -3.25, 0.083, and 9.83, 2.06, 2.86 , respectively, while, for the dyed cotton fabrics, the $a^{*}$ and $b^{*}$ values were: $-0.79,1.66$, 1.16 and $5.51,8.45,7.81$, respectively. It can be concluded that the colors obtained for the textile materials dyed without using any mordant agent (metal salt) have a very limited color shade palette.

\section{Dyeing cotton and wool fabrics using different mordant agents}

In this part of the study, two different textile materials were dyed with two concentrations of black carrot extract obtained with the help of ultrasonic energy, using six metal salts, and following two different mordanting methods. The effects of combining these parameters are investigated below.

Effects of mordanting method and mordant agents on dyed cotton fabrics

When the results obtained for the dyed cotton samples are examined in terms of color shade and color yields $(K / S)$, as shown in
Table 4 , it can be easily observed that the obtained colors vary as a function of the metal salt used. Mostly, pastel colors were achieved, beige, purple, light yellow and buff tones being predominantly remarked. Especially, it may be seen that purple hues are more common among the colors obtained. An increase in the bio-dye concentration caused the color tones to change. Examining the $K / S$ values tabulated in Table 4, it can be noticed that, in all the combinations, they are very close to each other. It is considered that the most probable explanation for this situation lies in the fact that in the chemical structure of cotton, a limited number of binding sites are accessible for the dye molecules to attach to. The highest $K / S$ value (1.6) was reached for the -Fe-Pre-Mordanting1:1- process combination. On the other hand, the lowest $K / S$ value $(0.14)$ was obtained for the -Al-Sim-mordanting-1:1- process combination.

By using pre-mordanting methods for $1: 1$ dyeing, the $a^{*}$ values were found to be of $3.27>0.7>0.55>0.31>-1.1>-1.19, \quad$ in the following order of mordant agents: -Fe-Cr-Sn$\mathrm{Cu}-\mathrm{Zn}-\mathrm{Al}-$, respectively. As regards 1:10 


\section{HÜSEYIN BENLI}

dyeing, the $a^{*}$ values reached were of $6.27>4.62>1.67>1.08>0.09>-2.76$, in the following order of mordant agents: $-\mathrm{Cr}-\mathrm{Sn}-\mathrm{Cu}-$ $\mathrm{Fe}-\mathrm{Al}-\mathrm{Zn}$-, respectively. Moreover, in the case of simultaneous mordanting for 1:1 dyeing, the $a^{*}$ values reached $2.53>0.43>0.42>0.28>-$ $0.06>-1.21$, for $-\mathrm{Fe}-\mathrm{Cr}-\mathrm{Cu}-\mathrm{Sn}-\mathrm{Al}-\mathrm{Zn}$-, respectively; and for 1:10 dyeing: 0.85>$1.23>-1.31>-2.16>-2.37>-3.84$, for $-\mathrm{Sn}-\mathrm{Cr}-\mathrm{Zn}-$ $\mathrm{Al}-\mathrm{Fe}-\mathrm{Cu}-$, respectively. By pre-mordanting in $1: 1$ dyeing, the $b^{*}$ values were found to be of $16.76>10.48>8.37>7.7>4.89>1.95$, for $-\mathrm{Fe}-\mathrm{Cu}-$ $\mathrm{Cr}-\mathrm{Sn}-\mathrm{Al}-\mathrm{Zn}-$, respectively, and in $1: 10$ dyeing, of $5.17>2.51>2.16>-0.67>-1.67>-1.99$, for $-\mathrm{Fe}-\mathrm{Zn}-\mathrm{Cr}-\mathrm{Sn}-\mathrm{Al}-\mathrm{Cu}-$, respectively. Moreover, by simultaneous mordanting in $1: 1$ dyeing, the $b^{*}$ values were $15.93>14.35>7.35>5.99>5.73>1.26$, for $-\mathrm{Fe}-$ $\mathrm{Cu}-\mathrm{Cr}-\mathrm{Sn}-\mathrm{Al}-\mathrm{Zn}-$, respectively, and in $1: 10$ dyeing, $\quad 10.02>2.98>2.05>0.65>-2.73>-6.39$, for $-\mathrm{Cr}-\mathrm{Fe}-\mathrm{Zn}-\mathrm{Cu}-\mathrm{Sn}-\mathrm{Al}-$, respectively. The highest hue angles $\left(309.98^{\circ}\right)$ and the lowest hue angles $\left(18.99^{\circ}\right)$ were obtained for the -Premordanting-1:10-Cu- and -Pre-mordanting1:0-Cr- process combinations, respectively. At the same time, the highest $L^{*}$ value $(88.99)$ and the lowest $L^{*}$ value (61.18) was obtained for the -Simultaneous-mordanting-1:1-Al- and -Pre-mordanting-1:10-Fe- combinations, respectively.

Effects of mordanting method and mordant agents on dyed wool fabrics

According to the results obtained for the dyed woolen fabric samples (Table 5), it can be easily remarked that the metal salts used produced significant color changes. Generally, yellow, blue, green, purple, beige, mustard yellow, cream and magenta colors were obtained on wool after dyeing with black carrot extract. This color variability is like a harbinger of important advantages for dyers. With the same bio-dyestuff source, different colors could be provided by changing the mordant agent. It is can be noted that the increase in bio-dye concentration causes color tones to change.

Examining the data in Table 5, it may be remarked that the $K / S$ values achieved with all the combinations on wool are very different from each other. Due to the chemical structure of wool, it is highly receptive towards mordants and can easily bind with dyestuffs.

Table 3

CIE $L^{*} a^{*} b^{*}$ values and obtained colors for dyed cotton and wool samples (without mordant agent)

\begin{tabular}{|c|c|c|c|c|c|c|c|}
\hline \multirow{2}{*}{ Material } & \multirow{2}{*}{$\begin{array}{c}\text { CIE } \\
L^{*} a^{*} b^{*}\end{array}$} & \multicolumn{6}{|c|}{ Dye concentration } \\
\hline & & & 1: & & $1: 10$ & & $1: 100$ \\
\hline \multirow{6}{*}{ Cotton } & $K / S$ & 0.11 & & 0.35 & & 0.88 & \\
\hline & $L^{*}$ & 89.83 & & 79.97 & & 66.78 & \\
\hline & $a^{*}$ & 0.79 & & 1.66 & & 1.16 & \\
\hline & $b^{*}$ & 5.51 & & 8.45 & & 7.81 & \\
\hline & $C^{*}$ & 5.56 & & 8.61 & & 7.9 & \\
\hline & $h^{\circ}$ & 81.81 & $=$ & 78.9 & & 81.57 & \\
\hline \multirow{6}{*}{ Wool } & $K / S$ & 0.66 & & 0.99 & & 2.69 & \\
\hline & $L^{*}$ & 78.34 & & 65.02 & & 43.54 & \\
\hline & $a^{*}$ & -2.07 & & -3.25 & & 0.08 & \\
\hline & $b^{*}$ & 9.83 & & 2.06 & & -2.86 & \\
\hline & $C^{*}$ & 10.05 & & 3.84 & & 2.86 & \\
\hline & $h^{\circ}$ & 101.87 & & 147.64 & & 271.62 & \\
\hline
\end{tabular}

The highest $K / S$ value (6.02) was achieved for the -Cu-Pre-Mordanting-1:1- process combination. On the other hand, the lowest $K / S$ value (0.93) was obtained for the -AlSimultaneous-mordanting-1:10- process combination. When the pre-mordanting method was used in 1:1 dyeing, the $a^{*}$ values were found as 7.5 $>1.98>0.97>0.34>-1.56>-$ 2.46, for $-\mathrm{Fe}-\mathrm{Cu}-\mathrm{Al}-\mathrm{Sn}-\mathrm{Zn}-\mathrm{Cr}-$, respectively, while in 1:10 dyeing, -1.61>-3.02>-4.21>5.93>-6.21>-9.61, for -Cr-Fe-Cu-Zn-Sn-Al-, respectively.

Furthermore, with simultaneous mordanting in 1:1 dyeing, the $a^{*}$ values achieved were: 
$1.03>0.01>-0.1>-0.86>-1.7>-2.34$, for $-\mathrm{Sn}-\mathrm{Cu}-$ $\mathrm{Cr}-\mathrm{Fe}-\mathrm{Al}-\mathrm{Zn}-$, respectively, and in $1: 10$ dyeing, $-0.01>-1.75>-5.07>-6.23>-6.84>-7.41$, for -Cr-Zn-Sn-Fe-Cu-Al-, respectively. Also, with pre-mordanting in 1:1 dyeing, the $b^{*}$ values were found as $25.24>22.42>17.75>13.66>13.01>9.62$ for $\mathrm{Fe}-\mathrm{Cu}-\mathrm{Al}-\mathrm{Zn}-\mathrm{Cr}-\mathrm{Sn}-$, respectively, and in 1:10 dyeing, 12.09>7.78>7.37>2.22>0.76>-3.58 for -Cu-Al-Fe-Zn-Sn-Cr-, respectively.

Moreover, with simultaneous mordanting in 1:1 dyeing, the $b^{*}$ values were $19.07>16.89>15.73>12.67>12.29>11.69$ for $\mathrm{Cu}-\mathrm{Cr}-\mathrm{Sn}-\mathrm{Zn}-\mathrm{Fe}-\mathrm{Al}-$, respectively, and in 1:10 dyeing, $17.46>8.24>2.12>1.12>0>-5.72$ for $\mathrm{Cr}-\mathrm{Cu}-\mathrm{Sn}-\mathrm{Al}-\mathrm{Zn}-\mathrm{Fe}-$, respectively.

Table 4

Photos of dyed cotton fabrics using black carrot extract

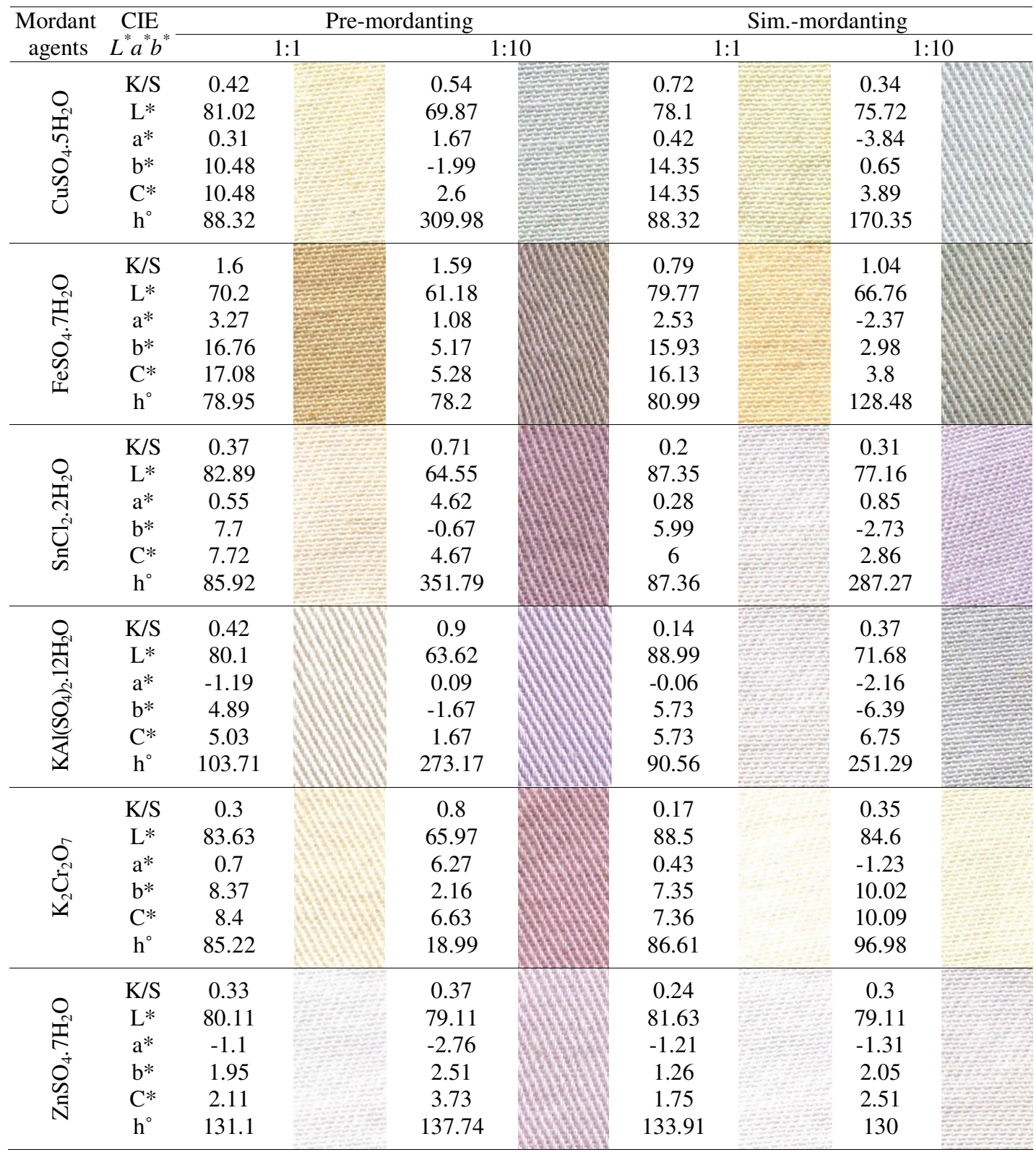

The highest hue angle $\left(245.78^{\circ}\right)$ and the lowest one $\left(73.45^{\circ}\right)$ were obtained for the -Premordanting-1:10-Cr- and -Pre-mordanting-1:1-
Fe- process combinations, respectively. At the same time, the highest $L^{*}$ value (77.94) and the lowest one (44.95) were recorded for the - 


\section{HÜSEYIN BENLI}

Simultaneous-mordanting-1:1-Al- and -Premordanting-1:10-Fe- process combinations, respectively. In the light of the data obtained, it can be observed that an unusual color variation is obtained by changing the mordant type, the mordanting method and bio-dye concentration.

Table 5

Photos of dyed wool fabrics using black carrot extract

\begin{tabular}{|c|c|c|c|c|c|}
\hline \multirow{2}{*}{$\begin{array}{c}\text { Mordant } \\
\text { agents }\end{array}$} & \multirow{2}{*}{ 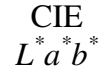 } & \multicolumn{2}{|c|}{ Pre-mordanting } & \multicolumn{2}{|c|}{ Sim.-mordanting } \\
\hline & & 1: & $1: 10$ & 1: & \\
\hline \multirow{6}{*}{ 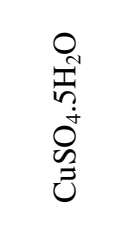 } & $\mathrm{K} / \mathrm{S}$ & 6.02 & 4.83 & 5.91 & 3.28 \\
\hline & $\mathrm{L}^{*}$ & 56.28 & 52.22 & 53.78 & 55.85 \\
\hline & $a^{*}$ & 1.98 & -4.21 & 0.01 & -6.84 \\
\hline & $\mathrm{b}^{*}$ & 22.42 & 12.09 & 19.07 & 8.24 \\
\hline & $\mathrm{C}^{*}$ & 22.51 & 12.81 & 19.07 & 10.71 \\
\hline & $\mathrm{h}^{\circ}$ & 84.94 & 109.18 & 89.98 & 129.69 \\
\hline \multirow{6}{*}{ 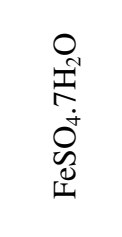 } & $\mathrm{K} / \mathrm{S}$ & 5.41 & 5.7 & 2.26 & 1.83 \\
\hline & $\mathrm{L}^{*}$ & 57.99 & 44.95 & 63.22 & 52.14 \\
\hline & $a^{*}$ & 7.5 & -3.02 & -0.86 & -6.23 \\
\hline & $b^{*}$ & 25.24 & 7.37 & 12.29 & -5.72 \\
\hline & $\mathrm{C}^{*}$ & 26.33 & 7.96 & 12.32 & 8.45 \\
\hline & $\mathrm{h}^{\circ}$ & 73.45 & 112.3 & 94.01 & 222.57 \\
\hline \multirow{6}{*}{ 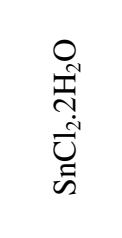 } & $\mathrm{K} / \mathrm{S}$ & 2.23 & 2.41 & 1.26 & 2.08 \\
\hline & $\mathrm{L}^{*}$ & 63.44 & 55.11 & 77.05 & 56.01 \\
\hline & $a^{*}$ & 0.34 & -6.21 & 1.03 & -5.07 \\
\hline & $b^{*}$ & 9.62 & 0.76 & 16.89 & 2.12 \\
\hline & $\mathrm{C}^{*}$ & 9.63 & 6.26 & 16.92 & 5.49 \\
\hline & $\mathrm{h}^{\circ}$ & 87.95 & 173.03 & 86.51 & 157.34 \\
\hline \multirow{6}{*}{ 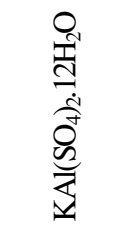 } & $\mathrm{K} / \mathrm{S}$ & 1.59 & 4.71 & 0.93 & 2.33 \\
\hline & $\mathrm{L}^{*}$ & 72.57 & 54.73 & 77.94 & 55.49 \\
\hline & $a^{*}$ & 0.97 & -9.61 & -1.7 & -7.41 \\
\hline & $b^{*}$ & 17.75 & 7.78 & 11.69 & 1.12 \\
\hline & $\mathrm{C}^{*}$ & 17.77 & 12.36 & 11.82 & 7.49 \\
\hline & $\mathrm{h}^{\circ}$ & 86.88 & 141 & 98.28 & 171.38 \\
\hline \multirow{6}{*}{ 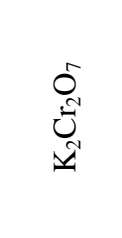 } & $\mathrm{K} / \mathrm{S}$ & 1.92 & 4.86 & 2.02 & 1.67 \\
\hline & $\mathrm{L}^{*}$ & 67.74 & 45.72 & 67.43 & 71.56 \\
\hline & $a^{*}$ & -2.46 & -1.61 & -0.1 & -0.01 \\
\hline & $b^{*}$ & 13.01 & -3.58 & 15.73 & 17.46 \\
\hline & $\mathrm{C}^{*}$ & 13.24 & 3.92 & 15.73 & 17.46 \\
\hline & $\mathrm{h}^{\circ}$ & 100.73 & 245.78 & 90.37 & 90.03 \\
\hline \multirow{6}{*}{ 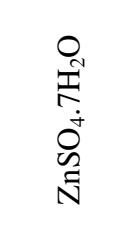 } & $\mathrm{K} / \mathrm{S}$ & 1.01 & 2.28 & 1.3 & 2.8 \\
\hline & $\mathrm{L}^{*}$ & 76.93 & 56.55 & 72.79 & 55.54 \\
\hline & $\mathrm{a}^{*}$ & -1.56 & -5.93 & -2.34 & -1.75 \\
\hline & $b^{*}$ & 13.66 & 2.22 & 12.67 & 0 \\
\hline & $\mathrm{C}^{*}$ & 13.75 & 6.34 & 12.89 & 1.75 \\
\hline & $\mathrm{h}^{\circ}$ & 96.5 & 159.47 & 100.45 & 179.85 \\
\hline
\end{tabular}


Textiles

Table 6

Color fastness values of cotton fabrics dyed using black carrot extract

\begin{tabular}{|c|c|c|c|c|c|c|c|c|c|c|c|}
\hline \multirow{5}{*}{$\begin{array}{c}\text { Mordanting } \\
\text { method }\end{array}$} & \multirow{3}{*}{$\begin{array}{l}\text { Dye } \\
\text { conc. }\end{array}$} & \multirow{3}{*}{ Mordant } & \multirow{2}{*}{\multicolumn{2}{|c|}{ Washing }} & \multirow{2}{*}{\multicolumn{2}{|c|}{ Rubbing }} & \multicolumn{4}{|c|}{ Perspiration } & \multirow{3}{*}{ Light } \\
\hline & & & & & & & \multicolumn{2}{|c|}{ Acidic } & \multicolumn{2}{|c|}{ Alkaline } & \\
\hline & & & Sta. & C.C. & Wet & Dry & Sta. & C.C. & Sta. & C.C. & \\
\hline & \multirow{2}{*}{$\begin{array}{c}1: 1 \\
1: 10\end{array}$} & \multirow{2}{*}{ No mordant } & $4 / 5$ & 5 & 5 & 5 & $4 / 5$ & 5 & 5 & 5 & $2 / 3$ \\
\hline & & & $4 / 5$ & 5 & 5 & 5 & 5 & 5 & 5 & 5 & $2 / 3$ \\
\hline \multirow{12}{*}{ 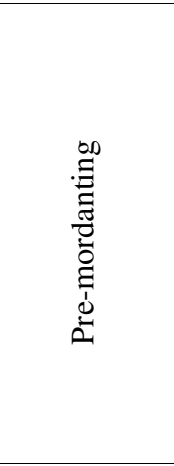 } & \multirow{6}{*}{$1: 1$} & $\mathrm{FeSO}_{4} \cdot 7 \mathrm{H}_{2} \mathrm{O}$ & 5 & 5 & $4 / 5$ & 5 & 5 & 5 & $4 / 5$ & 5 & 3 \\
\hline & & $\mathrm{CuSO}_{4} .5 \mathrm{H}_{2} \mathrm{O}$ & 5 & 5 & 5 & 5 & 5 & 5 & 5 & 5 & 3 \\
\hline & & $\mathrm{KAl}\left(\mathrm{SO}_{4}\right)_{2} \cdot 12 \mathrm{H}_{2} \mathrm{O}$ & 5 & 5 & 5 & 5 & 5 & 5 & 5 & 5 & $2 / 3$ \\
\hline & & $\mathrm{SnCl}_{2} .5 \mathrm{H}_{2} \mathrm{O}$ & $4 / 5$ & 5 & 5 & 5 & 5 & 5 & 5 & 5 & 3 \\
\hline & & $\mathrm{K}_{2} \mathrm{Cr}_{2} \mathrm{O}_{7}$ & 5 & 5 & 5 & 5 & 5 & $4 / 5$ & 5 & 5 & $2 / 3$ \\
\hline & & $\mathrm{ZnSO}_{4} \cdot 7 \mathrm{H}_{2} \mathrm{O}$ & 5 & 5 & 5 & 5 & 5 & 5 & 5 & 5 & $2 / 3$ \\
\hline & \multirow{6}{*}{$1: 10$} & $\mathrm{FeSO}_{4} .7 \mathrm{H}_{2} \mathrm{O}$ & $4 / 5$ & 5 & $4 / 5$ & 5 & $4 / 5$ & 5 & 5 & 5 & 3 \\
\hline & & $\mathrm{CuSO}_{4} .5 \mathrm{H}_{2} \mathrm{O}$ & $4 / 5$ & 5 & $4 / 5$ & 5 & 5 & 5 & 5 & 5 & 3 \\
\hline & & $\mathrm{KAl}\left(\mathrm{SO}_{4}\right)_{2} \cdot 12 \mathrm{H}_{2} \mathrm{O}$ & $4 / 5$ & 5 & $4 / 5$ & 5 & 5 & 5 & 5 & 5 & 3 \\
\hline & & $\mathrm{SnCl}_{2} .5 \mathrm{H}_{2} \mathrm{O}$ & 5 & 5 & 5 & 5 & $4 / 5$ & 5 & $4 / 5$ & 5 & $2 / 3$ \\
\hline & & $\mathrm{K}_{2} \mathrm{Cr}_{2} \mathrm{O}_{7}$ & 5 & 5 & 5 & 5 & $4 / 5$ & 5 & $4 / 5$ & 5 & $2 / 3$ \\
\hline & & $\mathrm{ZnSO}_{4} \cdot 7 \mathrm{H}_{2} \mathrm{O}$ & 5 & 5 & 5 & 5 & 5 & 5 & 5 & 5 & 3 \\
\hline \multirow{12}{*}{ 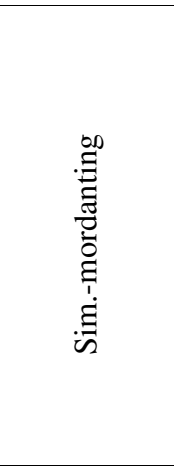 } & \multirow{6}{*}{$1: 1$} & $\mathrm{FeSO}_{4} .7 \mathrm{H}_{2} \mathrm{O}$ & $4 / 5$ & 5 & 5 & 5 & 5 & 5 & 5 & 5 & $2 / 3$ \\
\hline & & $\mathrm{CuSO}_{4} .5 \mathrm{H}_{2} \mathrm{O}$ & 5 & 5 & $4 / 5$ & 5 & $4 / 5$ & 5 & $4 / 5$ & 5 & $2 / 3$ \\
\hline & & $\mathrm{KAl}\left(\mathrm{SO}_{4}\right)_{2} \cdot 12 \mathrm{H}_{2} \mathrm{O}$ & 5 & 5 & 5 & 5 & $4 / 5$ & 5 & $4 / 5$ & 5 & $2 / 3$ \\
\hline & & $\mathrm{SnCl}_{2} \cdot 5 \mathrm{H}_{2} \mathrm{O}$ & 5 & 5 & 5 & 5 & $4 / 5$ & 5 & $4 / 5$ & 5 & 3 \\
\hline & & $\mathrm{K}_{2} \mathrm{Cr}_{2} \mathrm{O}_{7}$ & 5 & 5 & 5 & 5 & 5 & 5 & 5 & 5 & 3 \\
\hline & & $\mathrm{ZnSO}_{4} \cdot 7 \mathrm{H}_{2} \mathrm{O}$ & 5 & $4 / 5$ & 5 & 5 & 5 & 5 & 5 & 5 & 3 \\
\hline & & $\mathrm{FeSO}_{4} \cdot 7 \mathrm{H}_{2} \mathrm{O}$ & $4 / 5$ & $4 / 5$ & 5 & 5 & 5 & $4 / 5$ & 5 & 5 & 3 \\
\hline & & $\mathrm{CuSO}_{4} .5 \mathrm{H}_{2} \mathrm{O}$ & $4 / 5$ & $4 / 5$ & $4 / 5$ & 5 & $4 / 5$ & $4 / 5$ & 5 & 5 & $3 / 4$ \\
\hline & $1 \cdot 10$ & $\mathrm{KAl}\left(\mathrm{SO}_{4}\right)_{2} \cdot 12 \mathrm{H}_{2} \mathrm{O}$ & $4 / 5$ & $4 / 5$ & $4 / 5$ & 5 & $4 / 5$ & $4 / 5$ & $4 / 5$ & 5 & 4 \\
\hline & 1.10 & $\mathrm{SnCl}_{2} .5 \mathrm{H}_{2} \mathrm{O}$ & $4 / 5$ & 5 & 5 & 5 & $4 / 5$ & 5 & $4 / 5$ & 5 & $2 / 3$ \\
\hline & & $\mathrm{K}_{2} \mathrm{Cr}_{2} \mathrm{O}_{7}$ & 5 & 5 & 5 & 5 & 5 & 5 & 5 & 5 & 3 \\
\hline & & $\mathrm{ZnSO}_{4} \cdot 7 \mathrm{H}_{2} \mathrm{O}$ & 5 & 5 & 5 & 5 & 5 & 5 & 5 & 5 & 3 \\
\hline
\end{tabular}




\section{HÜSEYIN BENLI}

Table 7

Color fastness values of wool fabrics dyed using black carrot extract

\begin{tabular}{|c|c|c|c|c|c|c|c|c|c|c|c|}
\hline \multirow{5}{*}{$\begin{array}{c}\text { Mordanting } \\
\text { method }\end{array}$} & \multirow{3}{*}{$\begin{array}{l}\text { Dye } \\
\text { conc. }\end{array}$} & \multirow{3}{*}{ Mordant } & \multirow{2}{*}{\multicolumn{2}{|c|}{ Washing }} & \multirow{2}{*}{\multicolumn{2}{|c|}{ Rubbing }} & \multicolumn{4}{|c|}{ Perspiration } & \multirow{3}{*}{ Light } \\
\hline & & & & & & & \multicolumn{2}{|c|}{ Acidic } & \multicolumn{2}{|c|}{ Alkaline } & \\
\hline & & & Sta. & C.C. & Wet & Dry & Sta. & C.C. & Sta. & C.C. & \\
\hline & \multirow{2}{*}{$\begin{array}{c}1: 1 \\
1: 10\end{array}$} & \multirow{2}{*}{ No mordant } & 5 & 5 & 5 & 5 & $4 / 5$ & 5 & 5 & 5 & $2 / 3$ \\
\hline & & & 5 & 5 & 5 & 5 & 5 & 5 & 5 & 5 & $2 / 3$ \\
\hline \multirow{12}{*}{ 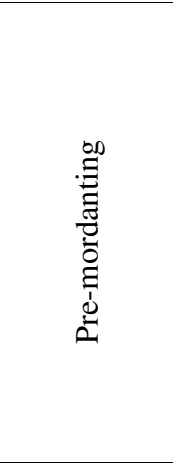 } & \multirow{6}{*}{$1: 1$} & $\mathrm{FeSO}_{4} .7 \mathrm{H}_{2} \mathrm{O}$ & $4 / 5$ & 5 & $4 / 5$ & 5 & 5 & 5 & 5 & 5 & 3 \\
\hline & & $\mathrm{CuSO}_{4} .5 \mathrm{H}_{2} \mathrm{O}$ & $4 / 5$ & 5 & $4 / 5$ & 5 & $4 / 5$ & 5 & 5 & 5 & 3 \\
\hline & & $\mathrm{KAl}\left(\mathrm{SO}_{4}\right)_{2} \cdot 12 \mathrm{H}_{2} \mathrm{O}$ & 5 & 5 & 5 & 5 & 5 & 5 & 5 & 5 & $3 / 4$ \\
\hline & & $\mathrm{SnCl}_{2} .5 \mathrm{H}_{2} \mathrm{O}$ & 5 & 5 & 5 & 5 & 5 & 5 & 5 & 5 & 4 \\
\hline & & $\mathrm{K}_{2} \mathrm{Cr}_{2} \mathrm{O}_{7}$ & 5 & 5 & 5 & 5 & 5 & $4 / 5$ & 5 & 5 & 3 \\
\hline & & $\mathrm{ZnSO}_{4} \cdot 7 \mathrm{H}_{2} \mathrm{O}$ & 5 & 5 & 5 & 5 & 5 & 5 & 5 & 5 & 4 \\
\hline & & $\mathrm{FeSO}_{4} .7 \mathrm{H}_{2} \mathrm{O}$ & $4 / 5$ & 5 & $4 / 5$ & 5 & $4 / 5$ & 5 & 5 & 5 & 4 \\
\hline & & $\mathrm{CuSO}_{4} .5 \mathrm{H}_{2} \mathrm{O}$ & 5 & 5 & 5 & 5 & 5 & 5 & 5 & 5 & 4 \\
\hline & & $\mathrm{KAl}\left(\mathrm{SO}_{4}\right)_{2} \cdot 12 \mathrm{H}_{2} \mathrm{O}$ & 5 & $4 / 5$ & 5 & 5 & 5 & 5 & 5 & 5 & 3 \\
\hline & $1: 10$ & $\mathrm{SnCl}_{2} .5 \mathrm{H}_{2} \mathrm{O}$ & 5 & 5 & 5 & 5 & 5 & 5 & 5 & 5 & 3 \\
\hline & & $\mathrm{K}_{2} \mathrm{Cr}_{2} \mathrm{O}_{7}$ & $4 / 5$ & 5 & 5 & 5 & $4 / 5$ & 5 & $4 / 5$ & 5 & $3 / 4$ \\
\hline & & $\mathrm{ZnSO}_{4} \cdot 7 \mathrm{H}_{2} \mathrm{O}$ & 5 & 5 & 5 & 5 & 5 & 5 & 5 & 5 & $3 / 4$ \\
\hline & & $\mathrm{FeSO}_{4} \cdot 7 \mathrm{H}_{2} \mathrm{O}$ & $4 / 5$ & $4 / 5$ & $4 / 5$ & 5 & 5 & 5 & 5 & 5 & 4 \\
\hline & & $\mathrm{CuSO}_{4} .5 \mathrm{H}_{2} \mathrm{O}$ & $4 / 5$ & 5 & $4 / 5$ & 5 & $4 / 5$ & 5 & $4 / 5$ & 5 & $3 / 4$ \\
\hline & $1 \cdot 1$ & $\mathrm{KAl}\left(\mathrm{SO}_{4}\right)_{2} \cdot 12 \mathrm{H}_{2} \mathrm{O}$ & 5 & $4 / 5$ & 5 & $4 / 5$ & 5 & 5 & $4 / 5$ & 5 & $3 / 4$ \\
\hline & $1: 1$ & $\mathrm{SnCl}_{2} .5 \mathrm{H}_{2} \mathrm{O}$ & 5 & $4 / 5$ & 5 & $4 / 5$ & 5 & 5 & $4 / 5$ & 5 & 4 \\
\hline 駡 & & $\mathrm{K}_{2} \mathrm{Cr}_{2} \mathrm{O}_{7}$ & 5 & $4 / 5$ & 5 & $4 / 5$ & 5 & 5 & 5 & 5 & 4 \\
\hline ప్రై & & $\mathrm{ZnSO}_{4} \cdot 7 \mathrm{H}_{2} \mathrm{O}$ & 5 & 5 & 5 & 5 & 5 & 5 & 5 & 5 & 4 \\
\hline 产 & & $\mathrm{FeSO}_{4} \cdot 7 \mathrm{H}_{2} \mathrm{O}$ & 5 & 5 & 5 & 5 & 5 & 5 & 5 & 5 & 3 \\
\hline$\stackrel{7}{1}$ & & $\mathrm{CuSO}_{4} .5 \mathrm{H}_{2} \mathrm{O}$ & 5 & 5 & 5 & 5 & 5 & $4 / 5$ & 5 & 5 & $4 / 5$ \\
\hline ڤ & $1 \cdot 10$ & $\mathrm{KAl}\left(\mathrm{SO}_{4}\right)_{2} \cdot 12 \mathrm{H}_{2} \mathrm{O}$ & $4 / 5$ & $4 / 5$ & $4 / 5$ & 5 & 5 & 5 & 5 & 5 & 3 \\
\hline & $1: 10$ & $\mathrm{SnCl}_{2} .5 \mathrm{H}_{2} \mathrm{O}$ & $4 / 5$ & 5 & 5 & 5 & $4 / 5$ & 5 & 5 & 5 & 3 \\
\hline & & $\mathrm{K}_{2} \mathrm{Cr}_{2} \mathrm{O}_{7}$ & 5 & 5 & 5 & 5 & 5 & 5 & 5 & 5 & 3 \\
\hline & & $\mathrm{ZnSO}_{4} \cdot 7 \mathrm{H}_{2} \mathrm{O}$ & 5 & 5 & 5 & 5 & 5 & 5 & 5 & 5 & $3 / 4$ \\
\hline
\end{tabular}


Color fastness of dyed samples

The color fastness test results of cotton and wool fabrics dyed with black carrot extract are presented in Tables 6 and 7. No adverse effects were found related to the type of the dyed material in terms of fastness properties. The rubbing, washing and perspiration fastness values for both cotton and woolen fabrics were obtained in the range of 4-5 points. It was noted that the mordanting methods and mordant types had no negative effects on the color fastness properties, especially, rubbing and washing fastness. The rubbing, perspiration and washing fastness tests yielded quite satisfactory results, for instance, the maximum grade (5) was observed.

The light fastness values of non-mordanted dyed samples were 1-2 points lower than those of mordanted dyed samples. The light fastness of all the rest of the dyed samples was found to range from low to medium. Most probably, the explanation for this is related to the metal salts used. A similar situation was observed by Ghaheh et al. ${ }^{54}$ The lowest light fastness value of $2 / 3$ was obtained as a result of dyeing without using any mordant. In the present study, the highest light fastness value was determined as 4 points for the dyed cotton fabric (-simultaneous-mordanting- $1: 10-\mathrm{Cu}$ combination) and $4 / 5$ points for the dyed wool fabric (-simultaneous-mordanting-1:10-Alcombination).

\section{SEM analysis}

The SEM images (recorded on a Zeiss evo LS10) of selected cotton and wool samples for surface analysis are shown in Figures 5 and 6. The surface of the dyed samples was examined to find out whether the bio-dyeing process produced any adverse effects on the materials. Observing the images in Figures 5 and 6, it can be concluded that that there is no big difference between the pre-treated samples and the randomly selected dyed ones for both the cotton and wool fabrics. No deformation caused by dyeing and the applied processes is observed in the flake layers of wool fibers. Therefore, it can be concluded that application of metal salts, black carrot bio-dye and heat treatments did not damage the fibers.

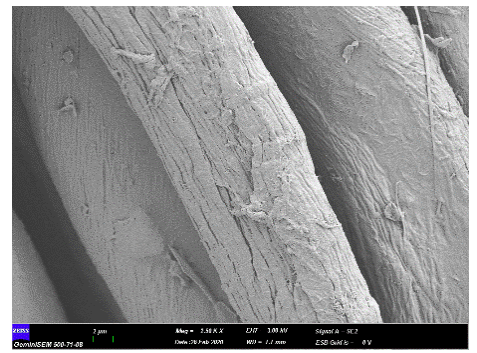

Pre-treated cotton

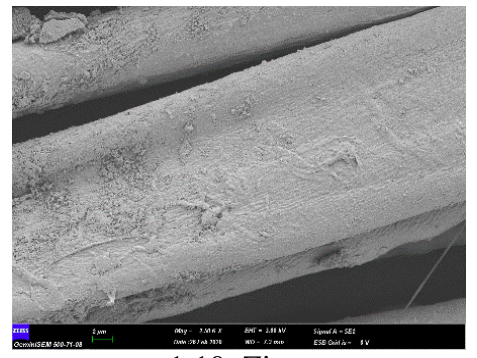

1:10_Zinc

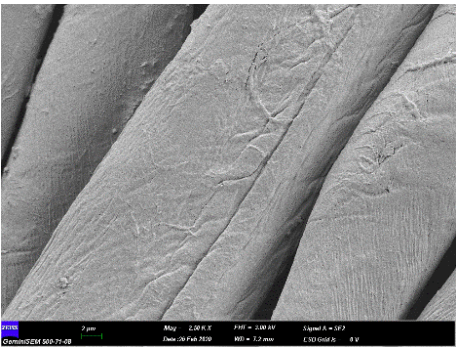

No mordant

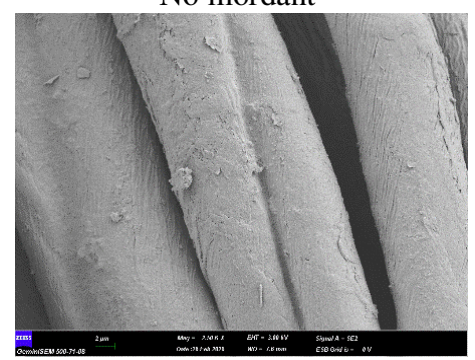

1:10_Copper

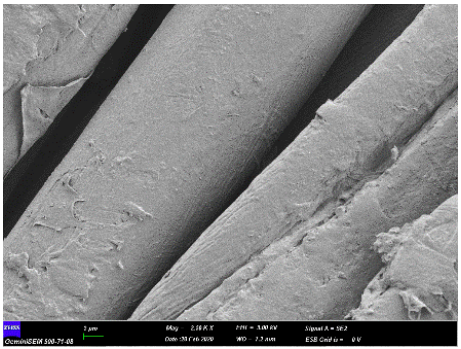

1:10_Tin

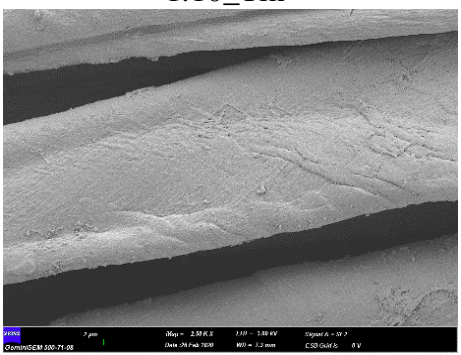

1:10_Alum

Figure 5: SEM images of selected cotton fabric samples dyed with black carrot extract 


\section{HÜSEYIN BENLI}

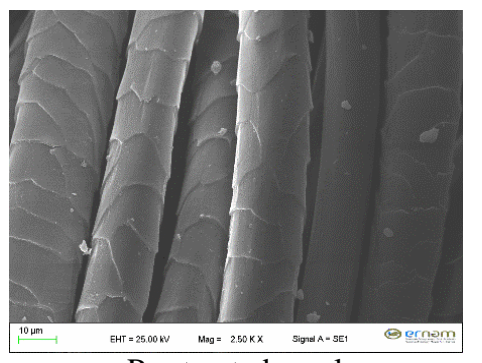

Pre-treated wool

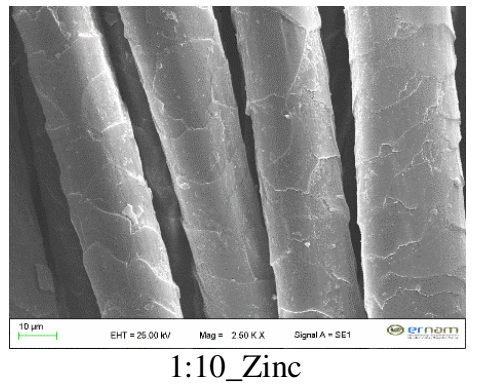

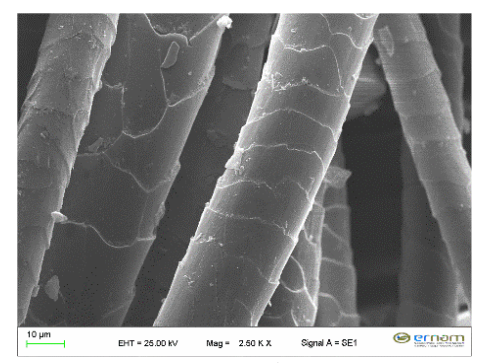

No mordant

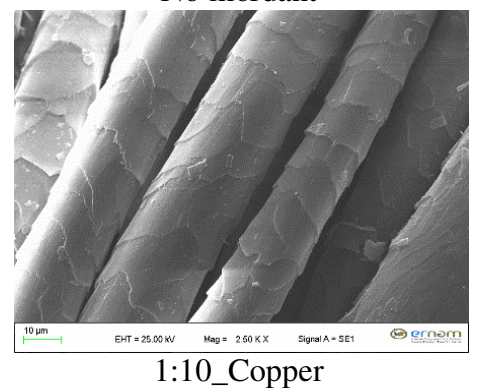

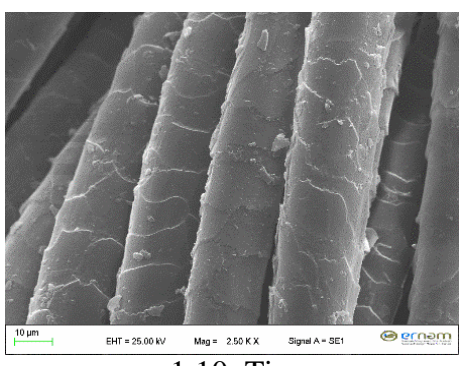

1:10_Tin

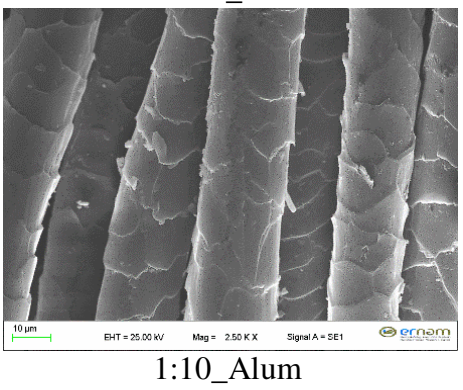

Figure 6: SEM images of selected wool fabric samples dyed with black carrot extract

\section{FTIR analysis}

As shown in Figures 7 and 8, FTIR spectra were recorded for different samples in the experimental part of the study, to examine any structural changes occurring in the materials. It can be seen in Figure 7 that there is no significant difference between the FTIR spectrum of the raw wool and those of selected dyed wool samples. Thus, it can be concluded that the wool fiber was not affected by the dyeing process using the black carrot extract, with different mordants and mordanting methods.

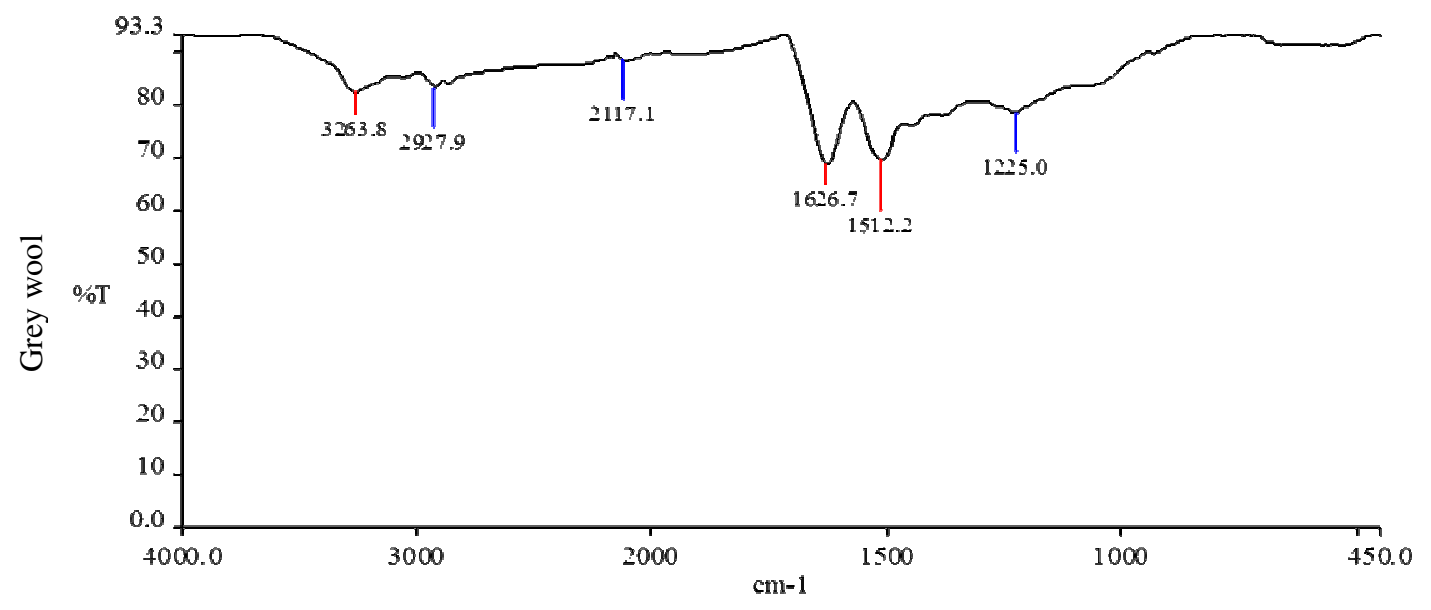


Textiles
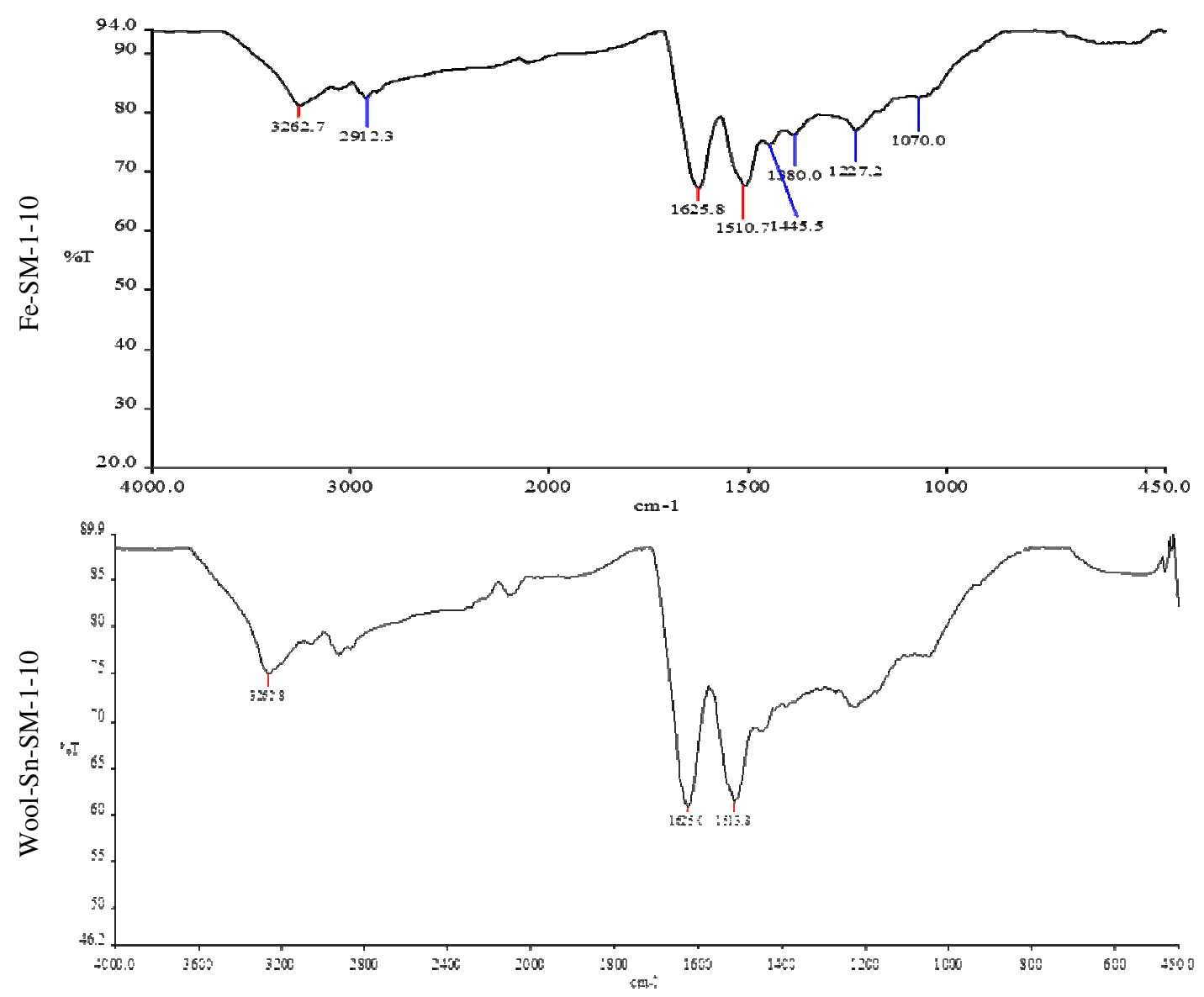

Figure 7: FTIR spectra of selected wool fabric samples dyed with black carrot extract

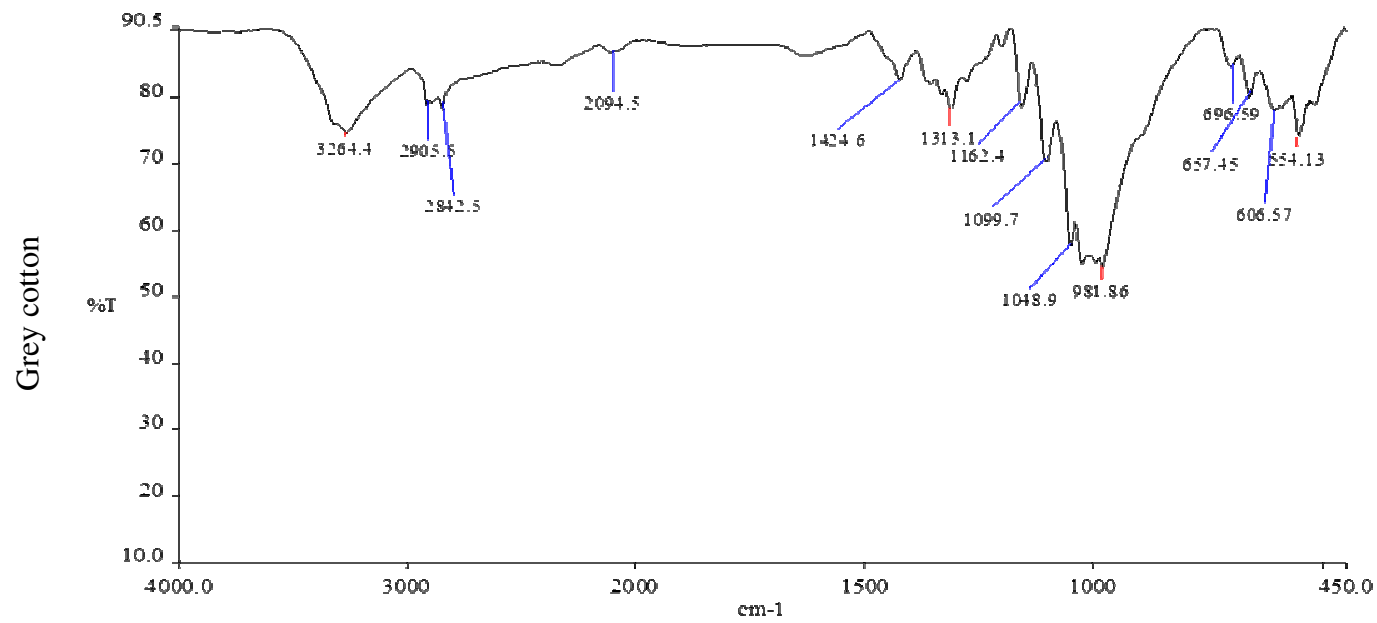




\section{HÜSEYIN BENLI}

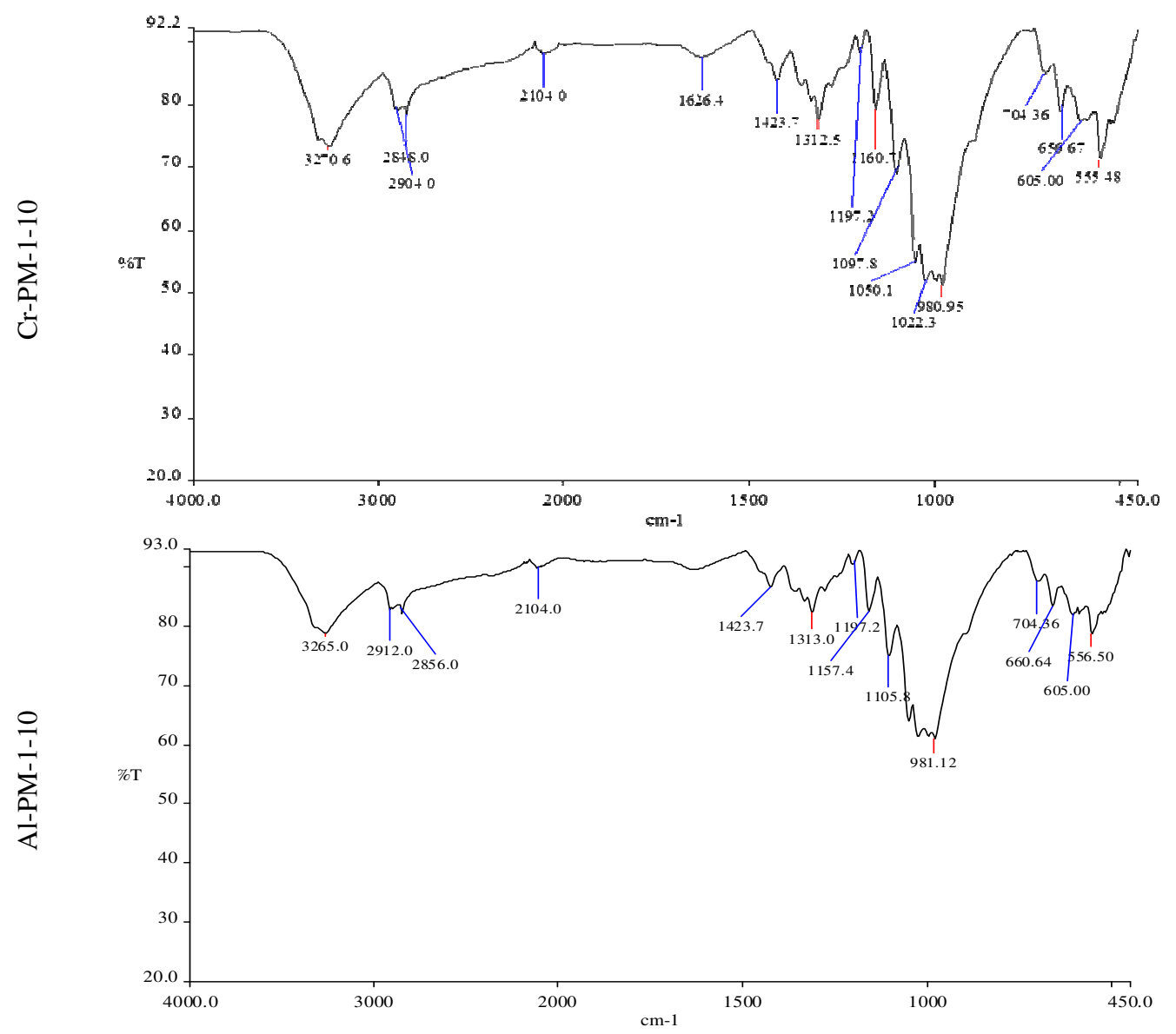

Figure 8: FTIR spectra of selected cotton fabric samples dyed with black carrot extract

Similar observations were made regarding the FTIR spectra of the raw cotton and of selected dyed cotton samples. The FTIR bands between $4000-400 \mathrm{~cm}^{-1}$ are known to belong to cellulose fibers. ${ }^{55-56}$ The peaks observed in the wavenumber range of $3600-2900 \mathrm{~cm}^{-1}$ correspond to individual stretching vibration of $\mathrm{O}-\mathrm{H}$ and $\mathrm{C}-\mathrm{H}$ bonds in polysaccharides. ${ }^{57}$ The broad peak at $3330 \mathrm{~cm}^{-1}$ is characteristic of the stretching vibration of the hydroxyl group in polysaccharides. The band at 2890 or 2090 $\mathrm{cm}^{-1}$ refers to the $\mathrm{CH}$ stretching vibration of all hydrocarbon constituents in polysaccharides. ${ }^{58}$ The characteristic bands assigned to cellulose are observed in the region of $1630-900 \mathrm{~cm}^{-1}$. The peaks located at 1630 or $1630 \mathrm{~cm}^{-1}$ correspond to the vibration of water molecules absorbed in cellulose. The absorption bands at $1425,1365,1330,1020 \mathrm{~cm}^{-1}$ and $896 \mathrm{~cm}^{-1}$ belong to stretching and bending vibrations of $-\mathrm{CH}$ and $-\mathrm{CH}_{2}, \mathrm{C}-\mathrm{O}$ and $-\mathrm{OH}$ bonds in cellulose. The band at around $1420-1430 \mathrm{~cm}^{-1}$ is related to the amount of the crystalline region in cellulose, while the band at $897 \mathrm{~cm}^{-1}$ refers to the amorphous region in cellulose.

\section{CONCLUSION}

Natural pigments from herbal sources, such as flavonoids, anthocyanins, quinones etc., are widely used in cosmetics, textiles, food, pharmaceutical and many other industries. These dyes have no toxic environmental and health risks, in contrast to their synthetic counterparts. In this study, cotton and woolen fabrics were dyed using a black carrot extract, which is a bio-based, biodegradable and nontoxic natural dyestuff obtained in aqueous medium, with the help of ultrasonic energy. An evaluation of the results obtained in the present work, such as color fastness properties, CIE $L * a * b *$ values, SEM images and FTIR spectra of the samples, allows the conclusion that the black carrot extract is a suitable bio-dye for coloring cotton and wool fabrics. It has been determined that the use of different metal salts will make a very important contribution to the variety of colors to be obtained. From this 
experimental study, it appears that it is possible to achieve a wide range of color shades, from beige to purple, on the examined fabrics. For future research, it is recommended to use the black carrot extract to dye different textile materials and determine the effects of different metal salts on the dyeing results.

\section{REFERENCES}

A. K. Samanta and P. Agarwal, Indian J. Fibre Tex., 34, 384 (2009)

2 M. J. Melo, in "Handbook of Natural Colorants", edited by T. Becktold and R. Mussak, Wiley, 2009

3 B. Chengaiah, K. M. Rao, K. M. Kumar, M. Alagusundaram and C. M. Chetty, Int. J. Pharm. Tech. Res., 2, $144 \quad$ (2010), http://sphinxsai.com/sphinxsaiVol_2No...

A. K. Samanta and A. Konar, in "Natural Dyes" edited by E. P. A. Kumbasar, InTech, Croatia, 2011

T. Bechtold, A. Mahmud-Ali and S Komboonchoo, in "Total Food" edited by K. W. Walden, G. K. Moates and C. B. Faulds, RSC Publishing, Cambridge, UK, 2009, pp. 211-218

6 D. Kammerer, R. Carle and A. Schieber, Rapid Commun. Mass Spectrom., 17, 2407 (2003), https://doi.org/10.1002/rcm.1212

V. Khandare, S. Walia, M. Singh and C. Kaur, Food Bioprod. Process., 89, 482 (2011), https://doi.org/10.1016/j.fbp.2010.07.007

8 A. Kırca, M. Özkan and B. Cemeroğlu, Food Chem., 101, 212 (2007), https://doi.org/10.1016/j.foodchem.2006.01.019

9 R. S. Verma, R. C. Padalia and A. Chauhan, Ind. Crop. Prod., 52, $809 \quad$ (2014), https://doi.org/10.1016/j.indcrop.2013.12.012

10 R. E. Wrolstad, J. Food Sci., 69, 419 (2004), https://doi.org/10.1111/j.1365-2621.2004.tb10709.x 11 B. Pant and S. Manandhar, Scientific World, 5, 51 (2007), https://doi.org/10.3126/sw.v5i5.2656

12 P. G. Rossi, L. Berti, J. Panighi, A. Luciani, J. Maury et al., J. Essent. Oil Res., 19, 176 (2007), https://doi.org/10.1080/10412905.2007.9699254

13 A. C. Tavares, M. J. Goncalves, C. Cavaleiro, M. T. Cruz, M. C. Lopes et al., J. Ethnopharmacol., 119, 129 (2008), https://doi.org/10.1016/j.jep.2008.06.012

14 A. Bishayee, A. Sarkar and M. Chatterjee, J. Ethanopharmacol., 47, $69 \quad$ (1995), https://doi.org/10.1016/0378-8741(95)01254-B

15 M. Q. Saleem, S. Akhtar, M. Imran, M. Riaz, A. Rauf et al., Z. Arznei- Gewurzpla, 22, 40 (2018) 16 M. Netzel, G. Netzel, D. R. Kammerer, A. Schieber, R. Carle et al., Innov. Food Sci. Emerg., 8, $365 \quad$ (2007), https://doi.org/10.1016/j.ifset.2007.03.011
17 A. Downham and P. Collins, Int. J. Food Sci. Tech., 35, 5 (2000), https://doi.org/10.1046/j.13652621.2000.00373.x

18 S. Ersus and U. Yurdagel, J. Food Eng., 80, 805

(2007),

https://doi.org/10.1016/j.jfoodeng.2006.07.009

19 S. Murali, A. Kar, D. Mohapatra and P. Kalia, Food Sci. Technol. Int., 21, 604 (2014), https://doi.org/10.1177/1082013214557843

20 G. Calogero and G. Di Marco, Sol. Energ. Mater. Sol. C., 92, $1341 \quad$ (2008), https://doi.org/10.1016/j.solmat.2008.05.007

21 S. Tekerek, A. Kudret and Ü. Alver, Indian J. $\begin{array}{llll}\text { Phys., } & \mathbf{8 5}, & 1469 & \text { (2011), }\end{array}$ https://doi.org/10.1007/s12648-011-0166-8

22 M. R. Narayan, Renew. Sust. Energ. Rev., 16, 208

(2012),

https://doi.org/10.1016/j.rser.2011.07.148

${ }_{23}$ E. M. Abdou, H. S. Hafez, E. Bakir and M. S. A. Abdel-Mottaleb, Spectrochim. Acta A, 115, 202 (2013), https://doi.org/10.1016/j.saa.2013.05.090

24 A. A. Al-Ghamdi, R. K. Gupta, P. K. Kahol, S. Wageh, Y. A. Al-Turki et al., Solid State Commun., 183 56

(2014), https://doi.org/10.1016/j.ssc.2013.12.021

25 M. Hosseinnezhad, S. Moradian and K. Gharanjig, Prog. Color Colorants Coat., 8, 153 (2015),

https://www.sid.ir/en/journal/ViewPaper.aspx?id=4 55468

26 S. Shalini, R. B. Prabhu, S. Prasanna, T. K. Mallick and S. Senthilarasu, Renew. Sust. Energ. Rev., $\quad 51, \quad 1306 \quad$ (2015), https://doi.org/10.1016/j.rser.2015.07.052

27 M. Vouters, P. Rumeau, P. Tierce and S. Costes, Ultrason. Sonochem., 11, 33 (2004), https://doi.org/10.1016/S1350-4177(03)00113-5

28 B. Niemczewski, Ultrason. Sonochem., 14, 13 (2007), https://doi.org/10.1016/j.ultsonch.2005.11.009

${ }_{29}$ S. Perincek, E. Uzgur, K. Duran, A. Dogan, A. E. Korlu et al., Ultrason. Sonochem., 16, 184 (2009), https://doi.org/10.1016/j.ultsonch.2008.06.003

${ }_{30}$ S. J. McNeil and R. A. McCall, Ultrason. Sonochem., $\quad \mathbf{1 8}, \quad 401 \quad$ (2011), https://doi.org/10.1016/j.ultsonch.2010.07.007

31 M. M. Kamel, M. M. El Zawahry, N. S. E. Ahmed and F. Abdelghaffar, Ultrason. Sonochem., 16, 243 (2009), https://doi.org/10.1016/j.ultsonch.2008.08.001

${ }_{32}$ V. Sivakumar, J. L. Anna, J. Vijayeeswarri and G. Swaminathan, Ultrason. Sonochem., 16, 782 (2009),

https://doi.org/10.1016/j.ultsonch.2009.03.009

33 A. Guesmi, N. Ladhari and F. Sakli, Ultrason. Sonochem., $\quad 20, \quad 571 \quad$ (2013), https://doi.org/10.1016/j.ultsonch.2012.04.012

34 M. Khatri, F. Ahmed, A. W. Jatoi, R. B. Mahar, Z. Khatri et al., Ultrason. Sonochem., 31, 


\section{HÜSEYIN BENLI}

350

https://doi.org/10.1016/j.ultsonch.2016.01.020

(2016)

A. A. Babar, N. Bughio, M. H. Peerzada, T. Naveed and A. Q. Dayo, Ultrason. Sonochem., 58, 104611 https://doi.org/10.1016/j.ultsonch.2019.05.028

36 P. Petkova, A. Francesko, I. Perelshtein, A. Gedanken and T. Tzanov, Ultrason. Sonochem., 29, 244

(2016),

https://doi.org/10.1016/j.ultsonch.2015.09.021

37 T. Harifi and M. Montazer, Ultrason. Sonochem., $\quad 37, \quad 158 \quad$ (2017), https://doi.org/10.1016/j.ultsonch.2017.01.006

38 H. Benli and M. I. Bahtiyari, J. Clean. Prod., 89, 116 https://doi.org/10.1016/j.jclepro.2014.11.007 (2015),

H. Benli and M. I. Bahtiyari, Cellulose, 22, 867 (2015), https://doi.org/10.1007/s 10570-014-0494-x

40 T. Bahorun, A. Luximon-Ramma, A. Crozier and O. I. Aruoma, J. Sci. Food Agric., 84, 1553 (2004), https://doi.org/10.1002/jsfa.1820

41 S. Akhtar, A. Rauf, M. Imran, M. Qamar, M. Riaz and M. S. Mubarak, Trends Food Sci. Tech., 66, 36

(2017),

https://doi.org/10.1016/j.tifs.2017.05.004

${ }^{42}$ P. J. Wakelyn, N. R. Bertoniere, A. D. French, D. P. Thibodeaux, B. A. Triplett et al., in "Handbook of Fiber Chemistry" edited by M. Lewin, CRC Press, Taylor \& Francis Group, Boca Raton USA, 2007, p. 620

43 E. Csiszár, A. Losonczi, G. Szakács, I. Rusznák, L. Bezúr et al., J. Biotechnol., 89, 271 (2001), 1656(01)00315-7

44 M. Prabaharan and J. V. Rao, Indian J. Fibre Text., 28, $437 \quad$ (2003), http://hdl.handle.net/123456789/22684

45 DIN 53924, Testing of Textiles and Velocity of Soaking Water of Textile Fabrics (Method by Determining the Wicking Height). Deutsches Institut Fur Normung E.V., Berlin (1997), https://www.beuth.de/en/standard/din53924/1637440

46 M. Shahid, S. Islam and F. Mohammad, J. Clean Prod., 53, $310 \quad$ (2013), https://doi.org/10.1016/j.jclepro.2013.03.031
47 S. J. Kadolph and K. D. Casselman, Cloth. Text. Res. J., 22, $15 \quad$ (2004), https://doi.org/10.1177/0887302X0402200103

48 K. J. Smith, in "Colour Physics for Industry" edited by R. McDonald, JSDC, Bradford, England, 1997, pp. 121-208

49 ISO 105-C10, Textiles-Tests for Color Fastness e Part C10: Color Fastness to Washing with Soap or Soap and Soda, Test Condition: Test A (1). ISO: Geneva, Switzerland, 2006

50 ISO 105-E04, Textiles-Tests for color fastness, Part E04: Color fastness to perspiration, International Organization for Standardization, Brussels, Belgium, 1994

51 ISO 105-B02, Textiles-Tests for Color Fastness, Part B02: Color Fastness to Artificial Light. ISO: Brussels, Belgium, 1994

52 ISO 105-X12, Textiles-Tests for Color Fastness, Part X12: Color Fastness to Rubbing. ISO: Geneva, Switzerland, 1993

53 P. S. Vankar, "Natural Dyes for Textiles: Sources, Chemistry and Applications", The Textile Institute Book Series, Matthew Deans, UK, 2017

54 F. S. Ghaheh, S. M. Mortazavi, F. Alihosseini, A. Fassihi, A. S. Nateri et al., J. Clean Prod., 72, 139 https://doi.org/10.1016/j.jclepro.2014.02.050 (2014), P. Garside and P. Wyeth, Stud. Conserv., 48, 269 (2003), https://doi.org/10.1179/sic.2003.48.4.269

56 V. Hospodarova, E. Singovszka and N. Stevulova, Am. J. Anal. Chem., 9, 303 (2018), https://doi.org/10.4236/ajac.2018.96023

57 A. Munajad and C. Subroto, Energies, 11, 1 (2018), https://doi.org/10.3390/en11020364

58 S. Y. Oh, D. I. Yoo, Y. Shin and G. Seo, Carbohyd. Res., 340, 417 (2005), https://doi.org/10.1016/j.carres.2004.11.027

59 Y. Ren, R. Fu, K. Fang, W. Chen, L. Hao et al., Ind. Crop. Prod., 142, 111863 (2019), https://doi.org/10.1016/j.indcrop.2019.111863

${ }^{60}$ T. Lohtander, S. Arola and P. Laaksonen, Color Technol, $\quad$ 136, 3 (2020), https://doi.org/10.1111/cote.12442

${ }^{61}$ S. Ul-Islam and B. S. Butola, Int. J. Biol. Macromol., $\quad$ 158, $94 \quad$ (2020), https://doi.org/10.1016/j.ijbiomac.2020.04.209 